九州大学学術情報リポジトリ

Kyushu University Institutional Repository

\title{
Capsule Set, Seed Productivity and Germination in Interspecific Crosses among Evergreen Azaleas
}

\section{Michishita, Ayano}

Laboratory of Horticultural Science, Division of Agricultural Botany, Department of Plant Resources, Graduate School of Bioresource and Bioenvironmental Sciences, Kyushu University

Ureshino, Kenji

Laboratory of Olericultural and Florocultural Sciences, Faculty of Agriculture, Iwate University

\section{Sakai, Kaori}

Laboratory of Horticultural Science, Division of Agricultural Botany, Department of Plant Resources, Graduate School of Bioresource and Bioenvironmental Sciences, Kyushu University

Ozaki, Yukio

Laboratory of Horticultural Science, Division of Agricultural Botany, Department of Plant Resources, Faculty of Agriculture, Kyushu University

https://doi.org/10.5109/4497

出版情報：九州大学大学院農学研究院紀要. 47 (2)，pp. 283-288，2003-02-01. Faculty of Agriculture, Kyushu University

バージョン：

権利関係: 
J. Fac. Agr., Kyushu Univ., 47 (2), 283-288 (2003)

\title{
Capsule Set, Seed Productivity and Germination in Interspecific Crosses among Evergreen Azaleas
}

\author{
Ayano MICHISHITA' ${ }^{1 \dagger}$, Kenji URESHINO², Ikuo MIYAJIMA, \\ Kaori SAKAI ${ }^{1}$ and Yukio OZAKI
}

\author{
Laboratory of Horticultural Science, Division of Agricultural Botany, Department of \\ Plant Resources, Faculty of Agriculture, Kyushu University, \\ Fukuoka 812-8581, Japan \\ (Received October 29, 2002 and accepted November 7, 2002)
}

\begin{abstract}
Crossability among seven evergreen azaleas (Rhododendron spp.) in subsection Tsutsusi was compared. Capsule set was observed in all the crosses. Number of seeds per capsule was lower in the crosses with $R$. kiusianum or $R$. serpyllifolium than in other crosses, and small flowers with short style and small ovary may be the reason for lower number of seeds. Number of seeds per capsule was maximum when male/female style length ratio (SLR) was around 0.7. The number gradually decreased as the increase of SLR, and above 2.2 of SLR resulted in $<200$ seeds, approving the relationship between SLR and number of seeds per capsule. The seeds germinated very well in the most crosses. In the crosses with $R$. serpyllifolium, however, unilateral cross incompatibility was observed.
\end{abstract}

\section{INTRODUCTION}

Many cultivated varieties of evergreen azalea (Rhododendron spp.) have been developed through the interspecific crosses. The knowledge of cross compatibility among species is important for the effective breeding, particularly in the simultaneous selection of several desirable characteristics. There are some reports of interspecific cross compatibility among evergreen azaleas distributed in Japan (Tamura, 1963; Akabane et al., 1971; Kunishige, 1983; Yamaguchi et al., 1985). These reports, however, did not give enough information, because the crossability was evaluated by only the frequency of capsule sets using limited number of cross combinations. There are several evergreen azalea species with desirable characters in Japan. $R$. tosaense flowers in early spring, and $R$. serpyllifolium $\mathrm{f}$. usukiunzen has pale-yellow flowers. They are considered to be useful as cross parent, but have not been used yet. More detail information, such as frequency of viable seeds per capsule or of vigorous seedlings, is required to proceed the interspecific cross breeding efficiently.

In the present study, the crossability among several evergreen azaleas was compared.

' Laboratory of Horticultural Science, Division of Agricultural Botany, Department of Plant Resources, Graduate School of Bioresource and Bioenvironmental Sciences, Kyushu University

${ }^{2}$ Laboratory of Olericultural and Floricultural Science, Faculty of Agriculture, Iwate University, Morioka 020-8550, Japan

† Corresponding author (micisita@agr.kyushu-u.ac.jp) 


\section{MATERIALS AND METHODS}

\section{Plant materials, pollination and style length}

Twenty-one reciprocal interspecific crosses among six species and one variety of evergreen azaleas (Tables 1 and 2) were carried out during 3 April and 27 May 1996, or during 12 April and 24 April 1997. Flowers of seed parents were emasculated two or three days before anthesis, and the pistils were covered with paper bags to prevent them from any undesired pollen. The stigmas were pollinated with fresh pollen or one-year-old pollen stored at $-20^{\circ} \mathrm{C}$, and the pollinated flowers were isolated in paper bags for one month. Corolla diameter of three flowers and style length of 20 flowers per plant were measured when plenty of the stigmatic exudate was observed.

Table 1. Species of evergreen azalea used as parents

\begin{tabular}{|c|c|c|c|c|}
\hline Species & Code & Series & Collection site & $\begin{array}{l}\text { Corolla } \\
\text { diameter }(\mathrm{cm})\end{array}$ \\
\hline $\begin{array}{l}\text { R. kaempferi } \\
\text { (Accession 1) }\end{array}$ & KAE1 & Kaempferia & $\begin{array}{l}\text { Mt. Kurokamiyama, } \\
\text { Saga Pref. }\end{array}$ & 3.6 \\
\hline $\begin{array}{l}\text { R. kaempferi var. macrogemma } \\
\text { (Accession } 1,2)\end{array}$ & KAM1, 2 & Kaempferia & $\begin{array}{l}\text { Izuoshima Is., } \\
\text { Tokyo }\end{array}$ & 4.1 \\
\hline $\begin{array}{l}\text { R. kiusianum } \\
\text { (Accession } 1,2)\end{array}$ & KIU1, 2 & Kaempferia & $\begin{array}{l}\text { Mt. Aso, } \\
\text { Kumamoto Pref. }\end{array}$ & 2.4 \\
\hline $\begin{array}{l}\text { R. serpyllifolium } \\
\text { (Accession } 1,2)\end{array}$ & SER1, 2 & Serpyllifolia & $\begin{array}{l}\text { Mt. Onogaradake, } \\
\text { Kagoshima Pref. }\end{array}$ & 1.4 \\
\hline $\begin{array}{l}\text { R. simsii } \\
\text { (Accession } 1)\end{array}$ & SIM1 & Kaempferia & $\begin{array}{l}\text { Iriomote Is., } \\
\text { Okinawa Pref. }\end{array}$ & 5.4 \\
\hline $\begin{array}{l}\text { R. tosaense } \\
\text { (Accession 1) }\end{array}$ & TOS1 & Kaempferia & $\begin{array}{l}\text { Hyuga City, } \\
\text { Miyazaki Pref. }\end{array}$ & 3.0 \\
\hline $\begin{array}{l}\text { R. transiens } \\
\text { (Accession 1) }\end{array}$ & TRA1 & Kaempferia & $\begin{array}{l}\text { Kanto area, } \\
\text { unknown }\end{array}$ & 5.5 \\
\hline
\end{tabular}

\section{Capsule set, number of seeds per capsule and seed germination}

Rate of capsule set was examined six months after crossing. The capsules were air-dried at $25^{\circ} \mathrm{C}$ for two weeks, and number of seeds per capsule was counted.

The seeds obtained from the above-mentioned crosses were soaked in $50 \mathrm{mgl}^{-1}$ of $\mathrm{GA}_{3}$ under dark condition at $25^{\circ} \mathrm{C}$ for $24 \mathrm{hrs}$ and sown on sphagnum. They were incubated at $25^{\circ} \mathrm{C}$ under a continuous light with cool-white fluorescent lamps of $25 \mu \mathrm{molm}^{-2} \mathrm{~s}^{-1} \mathrm{PPFD}$. Number of germinated seeds was counted after one month of culture.

\section{RESULTS}

Capsule set was observed in all the crosses (Table 2). A total of 149 capsules set in 165 pollinated flowers $(90.3 \%)$.

Number of seeds per capsule was less than 100 in five crosses: $R$. kaempferi var. macrogemma $\times R$. kiusianum, $R$. serpyllifolium $\times R$. kaempferi var. macrogemma, 
Table 2. Rate of capsule set to pollinated flowers in diallel interspecific crosses among evergreen azaleas

\begin{tabular}{lcccccccc}
\hline \multirow{2}{*}{ Female } & \multicolumn{7}{c}{ Male } \\
\cline { 2 - 8 } & KAE1 & KAM1 & KIU1 & SER1 & SIM1 & TOS1 & TRA1 & Total \\
\hline KAE1 & & $4 / 4^{\mathrm{a}}$ & $3 / 4$ & $4 / 4$ & $4 / 4$ & $4 / 4$ & $4 / 4$ & $23 / 24$ \\
KAM1 & $3 / 3$ & & $3 / 3$ & $2 / 3^{\mathrm{b}}$ & $3 / 3$ & $3 / 3$ & $3 / 4$ & $17 / 19$ \\
KIU1 & $3 / 3$ & $4 / 4$ & & $7 / 7$ & $3 / 3^{\mathrm{c}}$ & $4 / 5$ & $4 / 4$ & $25 / 26$ \\
SER1 & $3 / 3$ & $3 / 3^{\mathrm{b}}$ & $3 / 3$ & & $3 / 8$ & $3 / 3$ & $4 / 5$ & $19 / 25$ \\
SIM1 & $3 / 3$ & $2 / 3$ & $3 / 4^{\mathrm{c}}$ & $2 / 3$ & & $3 / 3$ & $3 / 3$ & $16 / 19$ \\
TOS1 & $3 / 3$ & $6 / 9$ & $4 / 4$ & $8 / 8$ & $3 / 3$ & & $7 / 7$ & $31 / 34$ \\
TRA1 & $3 / 3$ & $3 / 3$ & $3 / 3$ & $3 / 3$ & $3 / 3$ & $3 / 3$ & & $18 / 18$ \\
Total & $18 / 18$ & $22 / 26$ & $19 / 21$ & $26 / 28$ & $19 / 24$ & $20 / 21$ & $25 / 27$ & $149 / 165$ \\
\hline
\end{tabular}

a (Number of capsules six months after crossing)/(number of pollinated flowers).

b Results of the reciprocal crosses between KAM2 and SER2.

c Results of the reciprocal crosses between KIU2 and SIM1.

Table 3. Number of seeds per capsule in diallel interspecific crosses among evergreen azaleas

\begin{tabular}{lcclllllc}
\hline \multirow{2}{*}{ Female } & \multicolumn{7}{c}{ Male } \\
\cline { 2 - 8 } & KAE1 & KAM1 & KIU1 & SER1 & SIM1 & TOS1 & TRA1 & Mean \\
\hline KAE1 & & $430 \pm 34^{\mathrm{a}}$ & $53 \pm 22$ & $294 \pm 47$ & $329 \pm 63$ & $487 \pm 9$ & $188 \pm 24$ & 297 \\
KAM1 & $948 \pm 62$ & & $95 \pm 34$ & $501^{\mathrm{b}}$ & $772 \pm 259$ & $672 \pm 36$ & $546 \pm 244$ & 589 \\
KIU1 & $92 \pm 9$ & $143 \pm 13$ & & $174 \pm 36$ & $197 \pm 50^{\mathrm{c}}$ & $131 \pm 41$ & $179 \pm 40$ & 153 \\
SER1 & $277 \pm 16$ & $60 \pm 18^{\mathrm{b}}$ & 306 & & $28 \pm 18$ & $260 \pm 6$ & $129 \pm 6$ & 177 \\
SIM1 & $593 \pm 124$ & 750 & $104 \pm 10^{\mathrm{c}}$ & 169 & & $620 \pm 23$ & $384 \pm 74$ & 437 \\
TOS1 & $489 \pm 43$ & $372 \pm 30$ & $135 \pm 54$ & $197 \pm 74$ & $443 \pm 55$ & & $375 \pm 69$ & 335 \\
TRA1 & $438 \pm 49$ & $850 \pm 84$ & $311 \pm 40$ & $223 \pm 49$ & $972 \pm 68$ & $190 \pm 35$ & & 497 \\
Mean & 473 & 434 & 167 & 260 & 457 & 393 & 300 & 355 \\
\hline
\end{tabular}

a Mean土S.E.

besults of the reciprocal crosses between KAM2 and SER2.

c Results of the reciprocal crosses between KIU2 and SIM1.

$R$. serpyllifolium $\times R$. simsii, and the reciprocal crosses between $R$. kaempferi and $R$. kiusianum (Table 3). Above 500 seeds in a capsule were obtained in 10 crosses, and seed parents of the crosses were $R$. kaempferi var. macrogemma, $R$. simsii or $R$. transiens. Maximum number of seeds per capsule was apparently different by seed parents: $<200$ seeds in a capsule were in the crosses with $R$. kiusianum, $<400$ with $R$. serpyllifolium, $<500$ with $R$. kaempferi and $R$. tosaense, and $>700$ with $R$. kaempferi var. macrogemma, $R$. simsii and $R$. transiens. The big difference of seed number between reciprocal crosses was observed in five reciprocal crosses: $R$. kaempferi $\times R$. kaempferi var. macrogemma (430 vs. 948$), R$. kaempferi $\times R$. transiens (188 vs: 438$), R$. kaempferi var. macrogemma $\times R$. serpyllifolium (501 vs. 60$), R$. simsii $\times R$. serpyllifolium (28 vs. 169$)$ and $R$. simsii $\times R$. transiens (384 vs. 972$)$. Seed number by different capsules in one cross did not vary in 23 crosses, whereas the variation was dis- 
tinct in two crosses ( $R$. kaempferi var. macrogemma $\times R$. simsii and $R$. kaempferi var. macrogemma $\times R$. transiens), from which many seeds were obtained (546-772). Mean number of seeds was less than 260 in the crosses with $R$. kiusianum and $R$. serpyllifolium, whereas about 500 seeds were produced when $R$. kaempferi var. macrogemma, $R$. simsii and $R$. transiens were used as seed parents.

Male/female style length ratio (SLR) in the crosses using $R$. kaempferi var. macrogemma, $R$. simsii and $R$. transiens as seed parents was approximately less than 1.0 , and number of seeds per capsule varied by pollen parents, whereas $>800$ seeds were obtained when SLR was around $0.7(0.52-0.85)$ (Fig. 1). When the species with 2.0 to $3.0 \mathrm{~cm}$ of style length were used as seed parents, the range of SLR was $0.7-2.3$, and a maximum of 500 seeds was obtained in a capsule. Style of $R$. kiusianum was shorter than $2.0 \mathrm{~cm}$, and SLR in the crosses using this species as seed parents ranged from 1.1 to 2.8. All capsules in the crosses with $R$. kiusianum contained less than 200 seeds. The greatest number of seeds per capsule in all crosses was maximum when SLR was around 0.7 . It decreased gradually as SLR increased, and the number was less than 200 in $>2.2$ of SLR.

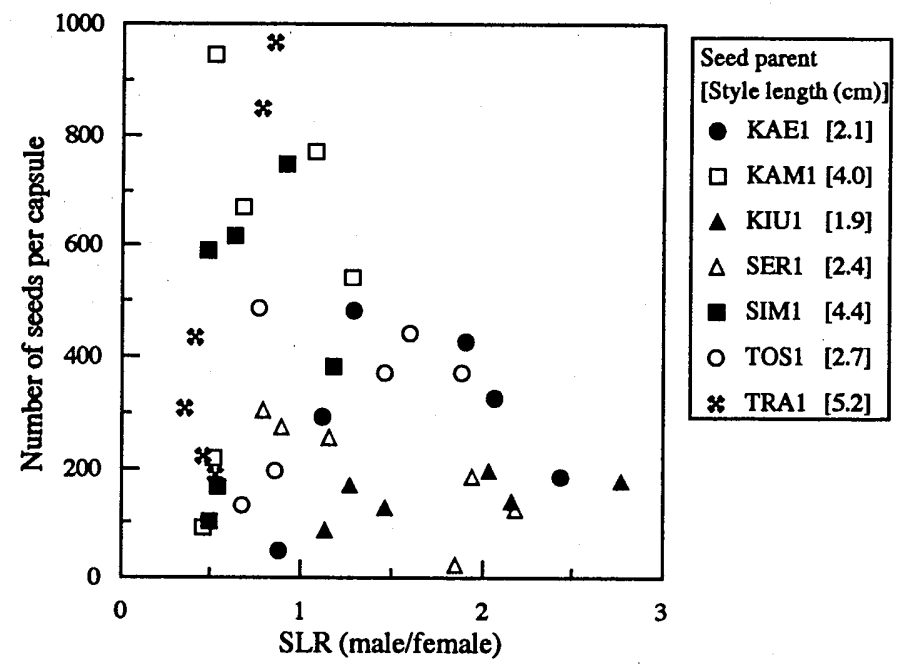

Fig. 1. Relationships between male/female style length ratio (SLR) and number of seeds per capsule in interspecific crosses among evergreen azaleas.

Seeds in the most crosses germinated, whereas all seeds obtained from the crosses using $R$. serpyllifolium as seed parents failed to germinate (Table 4 ). The percentages were $90 \%$ or over in seven crosses, and more than half of seeds germinated in all cross combinations excluding the crosses using $R$. serpyllifolium as pollen parents. The difference of the percentage between reciprocal crosses was below $10 \%$ in six reciprocal crosses. The whole average in all the crosses was $62.4 \%$. Many of the seedlings devel- 
Table 4. Percentage of germination (one month after sowing) of mature seeds harvested six months after crossing among evergreen azaleas

\begin{tabular}{lcccccccc}
\hline \multirow{2}{*}{ Female } & \multicolumn{7}{c}{ Male } \\
\cline { 2 - 9 } & KAE1 & KAM1 & KIU1 & SER1 & SIM1 & TOS1 & TRA1 & Mean \\
\hline KAE1 & & $84.7\left(300^{\circ}\right)$ & $58.3(24)$ & $43.5(214)$ & $70.4(101)$ & $55.7(300)$ & $55.2(105)$ & 61.3 \\
KAM1 & $88.3(300)$ & & $70.2(57)$ & $13.1(267)^{\mathrm{b}}$ & $94.7(300)$ & $92.7(300)$ & $92.0(300)$ & 75.2 \\
KIU1 & $90.5(42)$ & $79.8(228)$ & & $60.6(33)$ & $71.6(91)^{\mathrm{c}}$ & $87.8(41)$ & $88.9(127)$ & 79.9 \\
SER1 & $0(143)$ & $0(37)^{\mathrm{b}}$ & $0(80)$ & & $0(29)$ & $0(135)$ & $0(52)$ & 0 \\
SIM1 & $92.0(300)$ & $70.0(300)$ & $55.7(300)^{\mathrm{c}}$ & $67.9(84)$ & & $62.3(300)$ & $54.1(231)$ & 67.0 \\
TOS1 & $56.1(278)$ & $65.7(300)$ & $89.0(300)$ & $72.5(138)$ & $71.8(220)$ & & $60.3(300)$ & 69.2 \\
TRA1 & $91.5(200)$ & $79.3(300)$ & $82.7(300)$ & $77.0(139)$ & $90.0(300)$ & $86.1(129)$ & & 84.4 \\
Mean & 69.7 & 63.3 & 59.3 & 55.8 & 66.4 & 64.1 & 58.4 & 62.4 \\
\hline
\end{tabular}

a Number of sown seeds.

b Results of the reciprocal crosses between KAM2 and SER2.

c Results of the reciprocal crosses between KIU2 and SIM1.

oped green leaves and were vigorous, while albino, pale green or sectorial chimera plants were observed among seedlings from the crosses using $R$. serpyllifolium as a pollen parent. All the seedlings showed pale-green leaves in $R$. kaempferi var. macrogemma $\times R$. serpyllifolium and withered to die within a few weeks after germination.

\section{DISCUSSION}

There are reports that capsule set is generally high in interspecific crosses among evergreen azaleas (Tamura, 1963; Kunishige, 1983; Yamaguchi et al., 1985) in agreement with the results of the present study.

Number of seeds per capsule was apparently different by cross combinations. Two restricted factors are considered as to the seed number in a capsule. One is the pollen tube growth in a style. When pollen grains were pollinated to stigma of a very long pistil, number of pollen tubes reaching embryo sac might decrease (Williams and Rouse, 1990) and subsequently the seed number decreased. The other factor is ovary size because seed number is closely correlated with ovary size (Williams et al., 1990). In the crosses with $R$. kiusianum or $R$. serpyllifolium, seed number was smaller than in other crosses. These two species have small flowers with short style and small ovary (Table 1 and Fig. 1). These characters might have affected the seed number.

Williams et al. (1990) reported the relation between male/female style length ratio (SLR) and capsule set in interspecific crosses among species belonging to section Vireya in the genus Rhododendron. They showed that crosses with the species, having SLR of less than 0.2 or of greater than 6.0 , were all unsuccessful, and that the probability of success increased as the SLR reached 1.0. The SLR in the present study fluctuated from 0.4 to 2.8, and the capsules set in all the crosses, in agreement with the results of Williams $e t$ al. (1990). Number of seeds per capsule was maximum when the SLR was around 0.7. The number gradually decreased as the increase of SLR, and above 2.2 of SLR resulted in $<200$ seeds. A relationship between SLR and capsule set was already observed by 
Williams et al. (1990). The present data show that number of seeds per capsule is also related to SLR. The SLR would be a helpful marker index for obtaining number of seeds in crossing, and large number of flowers must be pollinated in the crosses with the above 2.0 of SLR.

The crossed seeds generally germinated very well in the most crosses. In the crosses with $R$. serpyllifolium, however, unilateral cross incompatibility was observed. The seeds hardly germinated in the crosses using this species as seed parents. In the reciprocal cross, relatively high rate of seed germination was observed, although most of the seedlings became albino and died during development. The species used in this study are all in the subsection Tsutsusi. $R$. serpyllifolium belongs to the series Serpyllifolia, whereas the rest to the series Kaempferia (Table 1). Cross incompatibility has been reported in intergeneric and intersectional crosses (Tamura, 1963; Yamaguchi et al., 1985; Rouse et al., 1993), and the unilateral cross incompatibility occurs frequently in the crosses between evergreen and deciduous azaleas (Noguchi, 1932; Akabane et al., 1971; Ureshino et al., 1998). Its occurrence was observed in the crosses among evergreen species in the same subsection in the present study.

It is summarized in the crosses within subsection Tsutsusi that 1) capsules generally set, 2) many seeds are produced in a capsule except for the crosses with small-flowered species, and 3) cross incompatibility might have occurred in the crosses with $R$. serpyllifolium.

\section{REFERENCES}

Akabane, M., A. Yamanaka, D. Takashima, T. Nakatsue and Y. Nakamura 1971 On the fertility of interspecific crossing and the growth of $\mathrm{F}_{1}$ seedlings in Rhododendron species. Bull. Tochigi Agr. Exp. Sta., 15: 95-102 (in Japanese)

Kunishige, M. 1983 Study of tsutsuji cultivars. Symposium Abstr. Japan. Soc. Hort. Sci. Autumn Meet.,: 100-109 (in Japanese)

Noguchi, Y. 1932 Studies on the species crosses of Japanese Rhododendron. I. On the crossability between various species and the cotyledon color of $\mathrm{F}_{1}$ seedlings. Japan. J. Bot., 6: 103-124

Rouse, J. L., R. B. Knox and E. G. Williams 1993 Inter- and intraspecific pollinations involving Rhododendron species. J. Amer. Rhododendron Soc., 47: 23-28

Tamura, T. 1963 Studies on the Hirado-azaleas, with special reference to their formation. Bull. Hort. Res. Sta., Japan, Ser. D, 1: 155-188 (in Japanese with English summary)

Ureshino, K., I. Miyajima and M. Akabane 1998 Effectiveness of three-way crossing for the breeding of yellow-flowered evergreen azalea. Euphytica, 104: 113-118

Williams, E. G. and J. L. Rouse 1990 Relationships of pollen size, pistil length and pollen tube growth rates in Rhododendron, and their influence on hybridization. Sex. Plant Reprod., 3: 7-17

Williams, E. G., J. L. Rouse, B. F. Palser and R. B. Knox 1990 Reproductive biology of rhododendron. Hort. Rev., 12: 1-67

Yamaguchi, S., M. Kunishige and T. Tamura. 1985 Interspecific compatibility in Japanese Rhododendron. Bull. Veg. and Ornam. Crops Res. Stn. Japan, Ser. C, 8: 87-97 (in Japanese with English summary) 